\title{
PERANCANGAN GEROBAK PEMULUNG SAMPAH ERGONOMIS DN PELATIHAN KEWIRAUSAHAAN (Studi Kasus: Kecamatan Bandung Wetan Kota Bandung)
}

\author{
Rohmana $^{1}$, Leni Herdiani ${ }^{1}$, Muliastuti Anggrahini ${ }^{3 *}$ \\ ${ }^{1}$ Program Studi Teknik Industri-Fakultas Teknik, Universitas Langlangbuana Bandung, Indonesia \\ ${ }^{3}$ Program Studi Manajemen-Fakultas Ekonomi dan Bisnis, Universitas Langlangbuana Bandung, Indonesia \\ *Email: anggrahini.muliastuti@gmail.com
}

\begin{abstract}
Informasi Artikel Abstrak
Kata kunci :

ergonomi, gerobak

sampah, pemulung,

kewirausahaan

Diterima: 21-04-2021

Disetujui: 02-07-2021

Dipubikasikan: 16-07-

2021

Pemulung merupakan suatu pekerjaan dengan mencari sampah bekas, baik kardus ataupun botol plastik yang masih dapat didaur ulang, sehingga dapat dijual ke agen. Gerobak yang digunakan pemulung untuk mengangkut sampah selama ini memiliki beberapa keterbatasan, mengakibatkan pengguna sering mengeluh kesakitan pada punggung, pinggang, tangan dan telapak tangan. Pemulung juga belum bisa memanfaatkan barang-barang bekas yang diperoleh untuk memiliki nilai ekonomis. Oleh sebab itu, perlu dilakukan perbaikan desain gerobak sampah yang aman, dan nyaman. Pelatihan juga diperlukan untuk meningkatkan kreativitas keluarga pemulung. Program ini merancang ulang gerobak pemulung dengan pendekatan ergonomis pada dimensi tubuh pengguna. Program ini juga memberikan pelatihan dasar-dasar kewirausahan dan pembuatanbarang kreasi dari barang bekas bagi keluarga pemulung. Gerobak pemulung hasil rancangan tim peneliti dapat menurunkan keluhan Nordic Body Map pemulung dari rata-rata sebesar $86,5 \%$ menjadi $40,2 \%$. Pelatihan kewirausahaan dan membuat barang kreasi meningkatkan kemampuan keluarga pemulung untuk meningkatkan nilai ekonomis barang-barang bekas di sekitar mereka.
\end{abstract}

\section{Keywords :}

ergonomics, garbage

carts, scavengers,

entrepreneurship

\section{Abstract}

Scavengers are a job by looking for used goods, either cardboard or plastic bottles that can still be recycled, so that they can be sold to agents. The carts used by scavengers to transport garbage have had several limitations, resulting in users often complaining of pain in the back, waist, hands and palms. Therefore, it is necessary to improve the design of the trash cart that is safe, and comfortable for its users. This program redesigns the scavenger cart with an ergonomic approach to the dimensions of the user's body. Scavengers also have not been able to utilize the used goods obtained to have economic value. Therefore, it is necessary to improve the design of a safe and comfortable garbage cart. Scavenger families also need training to develop creativity. This program redesigns the scavenger cart with an 
ergonomic approach to the dimensions of the user's body. This program also provides training on the basics of entrepreneurship and the create goods from used goods for their families. The results of the cart scavenger cart design can reduce the Nordic Body Map scavenger complaints from an average of $86.5 \%$ to $40.2 \%$. Entrepreneurship training and creating goods improve the ability of scavenger families to increase the economic value of used goods around them.

\section{PENDAHULUAN}

Pertumbuhan penduduk perkotaan Indonesia mencapai 4,1\% per tahun, lebih tinggi dibanding Cina 3,8\% dan India 3,1\%. Dengan level pertumbuhan yang seperti itu, Menteri Keuangan Sri Mulyani mengatakan pada 2025 sekitar 68\% penduduk negeri ini akan hidup di kota-kota. Salah satu masalah yang timbul dari peningkatan jumlah penghuni kota adalah produksi sampah yang terus naik. Kelompok miskin dan terpinggirkan di kota, yang pindah dari desa tapi tidak bisa masuk ke dalam pekerjaan formal, melihat sampah sebagai sumber mata pencaharian.

Pemulung adalah seseorang yang memiliki pekerjaan sebagai pencari barang yang sudah tidak terpakai. Dalam kenyataan sehari hari maka orang yang berkecimpung dalam proses pemulungan atau sebagai pemulung adalah orang yang bekerja sebagai pengais sampah, dimana antara pemulung dan sampah sebagai dua sisi mata uang. Dimana ada sampah pasti ada pemulung dan dimana ada pemulung disitu pasti ada sampah.

Aktivitas pemulung sampah ini dimulai dari mengambil atau memilah barang yang sudah tidak terpakai tapi masih bermanfaat yang ada pada tong-tong sampah perumahan, kemudian pemulung berjalan ke tempat penampungan sementara (TPS) yang telah tersedia dengan menggunakan gerobak. Di TPS tersebut pemulung kemudian mencari lagi barang-barang yang sudah tidak terpakai seperti botol bekas dan kardus untuk dikumpulkan kemudian baru disetorkan juragan barang bekas.

Salah satu tempat penampungan akhir dari sampah di Kota Bandung adalah TPA Kecamatan Bandung Wetan yang terletak di Jl. Ambon no 3. Pada tempat ini sampah ditempatkan sementara sebelum diangkut ke tempat daur ulang, pengolahan ataupun tempat pengolahan sampah terpadu.

Pada umumnya sampah yang dibuang manusia diletakkan begitu saja di tempat sampah menunggu tukang sampah datang untuk mengangkutnya. Akan tetapi terkadang sampah yang ada di tempat sampah terusik oleh aksi orang-orang yang berprofesi sebagai pemulung alias tukang beling. Sebagian sampah yang sudah dibuang orang terkadang diambil untuk berbagai kebutuhan hidupnya.

Barang-barang yang biasa diambil pemulung biasanya adalah: kardus bekas, botol toples atau benda yang terbuat dari kaca, besi bekas, botol/gelas plastik, barang bekas yang masih bisa dipergunakan, kaleng bekas susu, kemasan plastik berbahan tebal. Adapun barang bekas yang dapat dijadikan kreasi antara lain adalah botol bekas yang dapat dijadikan celengan, tempat pensil, kaleng bekas yang dapat dijadikan celengan, dll. 
Permasalahan yang dihadapi mitra antara lain adalah belum memiliki gerobak yang ergonomis sehingga menyebabkan produktivitas berkurang, belum terampil dalam hal pertukangan sehingga belum dapat membuat alat-alat kerja dari kayu seperti gerobak, belum terampil dalam mengolah keuangan dan pemasaran setelah nantinya dapat membuat alat-alat kerja dari kayu, serta istri para pemulung belum terampil dalam membuat benda-benda kreasi yang dapat dibuat dari barang bekas.

Ergonomi berasal dari Bahasa Latin yaitu ergon yang berarti "kerja" dan nomos yang berarti "hukum alam". Ergonomi dapat didefinisikan sebagai studi tentang aspek-aspek manusia dalam lingkungan kerjanya yang ditinjau secara anatomi, fisiologi, psikologi, engineering, manajemen dan desain/perancangan (Nurmianto, 2004). Ergonomi adalah suatu cabang ilmu yang sistematis untuk memanfaatkan informasi-informasi mengenai sifat, kemampuan dan keterbatasan manusia untuk merancang suatu system kerja sehingga orang dapat hidup dan bekerja pada sistem itu dengan baik, yaitu mencapai tujuan yang diinginkan melalui pekerjaan itu dengan efektif, aman dan nyaman (Sutalaksana et al., 1979).

Program ini menawarkan solusi dari permasalahan di atas berupa pembuatan gerobak sampah yang ergonomis dan ekonomis. Secara umum tujuan dari penerapan ergonomi adalah (1) meningkatkan kesejahteraan fisik dan mental melalui upaya pencegahan cedera dan penyakit akibat kerja, menurunkan beban kerja fisik dan mental, mengupayakan promosi dan kepuasan kerja, (2) meningkatkan kesejahteraan sosial melalui peningkatan kualitas kontak sosial, mengelola dan mengkoordinir kerja secara tepat guna dan meningkatkan jaminan sosial baik selama kurun waktu usia produktif maupun setelah tidak produktif, dan (3) menciptakan keseimbangan rasional antara berbagai aspek yaitu aspek teknis, ekonomis, antropologis dan budaya dari setiap sistem kerja yang dilakukan sehingga tercipta kualitas kerja dan kualitas hidup yang tinggi (Tarwaka et al., 2004).

Pada akhirnya program ini diharapkan dapat meningkatkan produktivitas pemulung, pemberian pelatihan pertukangan kepada para pemulung mengenai cara-cara pembuatan gerobak dan alat-alat dari kayu bekas dan besi bekas sehingga nantinya mereka mampu membuat berbagai peralatan dari bahan kayu bekas dan besi bekas tersebut dan nantinya dapat dijual sehingga pada akhirnya dapat meningkatkan pendapatan keluarga, pemberian pelatihan kewirausahaan pada pemulung dalam hal manajemen keuangan, manajemen produksi dan manajemen pemasaran untuk meningkatkan kemampuan berwirausaha. Dengan pelatihan kewirausahaan tersebut diharapkan dapat menumbuhkan jiwa kewirausahaan pada pemulung, dan pemberian pelatihan pembuatan barang-barang kreasi dari bahan bekas.

\section{METODE}

Kegiatan pengabdian masyarakat bertempat di penampungan akhir dari sampah di Kota Bandung yaitu TPA Kecamatan Bandung Wetan yang terletak di Jl. Ambon no 3. Dilaksanakan pada bulan September sd Oktober 2020. Kegiatan yang dilaksanakan meliputi pembuatan gerobak pemulung 
yang ergonomis dan ekonomis, pelatihan pembuatan perkakas yang berbahan kayu dan besi bekas, pelatihan pembuatan kreativitas dari barang bekas dan pelatihan kewirausahaan. Tahapan-tahapan dalam pembuatan gerobak pemulung sampah yang ergonomis dan ekonomis adalah a) identifikasi dan perumusan masalah; b) studi Pustaka; c) studi lapangan; d) pengumpulan data; e) perencanaan produk; f) house of quality; g) penyusunan konsep; h) penentuan spesifikasi akhir produk; i) prototyping; $\mathrm{j}$ ) pengujian prototype; $\mathrm{k}$ ) perhitungan biaya; 1 ) analisis hasil dan pembahasan, dan $\mathrm{m}$ ) kesimpulan dan saran.

Sedangkan tahapan-tahapan yang dilakukan dalam memberikan pelatihan kewirausahaan, pembuatan perkakas dan barang kreasi dari bahan bekas adalah a) mengkaji kebutuhan mitra; b) menetapkan permasalahan mitra; c) menyusun perencanaan pelatihan yang meliputi menetapkan tujuan, penentuan sasaran, penyusunan materi/isi pelatihan, pemilihan metoda yang tepat, menentukan jenis alat peraga yang akan digunakan, dan penentuan kriteria evaluasi; d) pelaksanaan pelatihan; dan e) penilaian hasil pelatihan.

Metode pelaksanaan kegiatan digambarkan sebagai berikut:

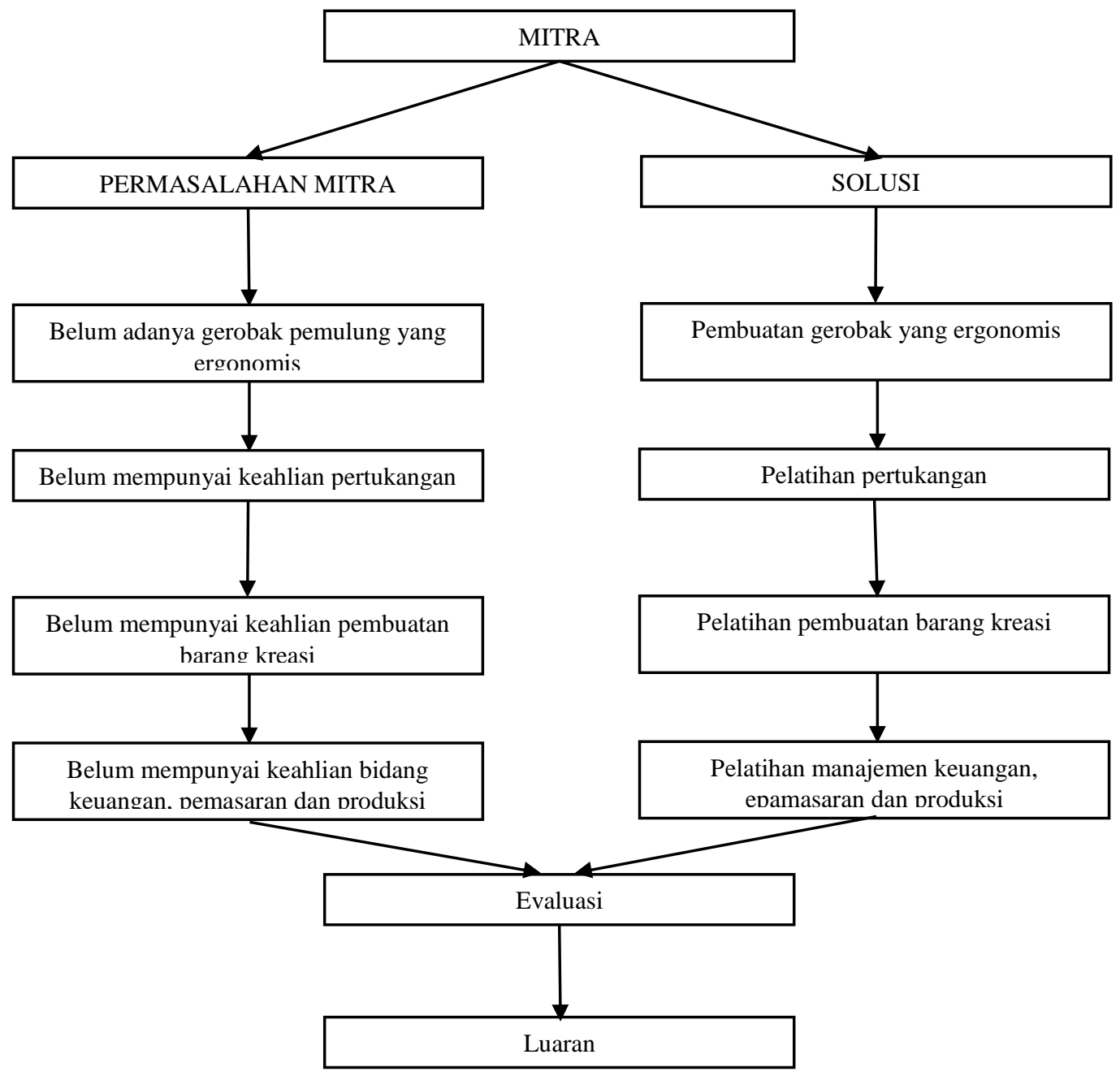

Gambar 1. Alur Program 
Metoda pelatihan yang digunakan adalah demonstrasi dengan Langkah pertama, yaitu persiapan, yang meliputi menetapkan tujuan, menentukan materi, menentukan sasaran dengan latar belakangnya, menentukan waktu dan perkiraan lamanya waktu demostrasi, menentukan alat-alat dan alat peraga yang akan digunakan, menyesuaikan materi yang akan disampaikan dengan demontrasi yang akan dilaksanakan, dan mengecek segala persiapan secara keseluruhan serta peralatan yang sudah dipersiapkan.

Langkah kedua adalah pelaksanaan, yang meliputi menjelaskan tujuan demonstrasi, menciptakan suasana yang akrab, menjelaskan materi yang didemonstrasikan, memberikan tekanan yang dianggap penting, dan memberikan kesempatan untuk tanya jawab. Sedangkan Langkah terakhir adalah penilaian yang meliputi banyaknya pertanyaan tentang materi dan prosedur yang didemonstrasikan dan kepuasan peserta pelatihan.

\section{HASIL DAN PEMBAHASAN}

\section{Perancangan Gerobak Pemulung Sampah yang Ergonomis}

Pemulung merupakan suatu pekerjaan dengan mencari sampah bekas baik itu kardus ataupun botol plastik yang masih dapat didaurulang sehingga dapat dijual kembali ke agennya. Gerobak yang dipergunakan pemulung untuk mengangkut sampah selama ini memiliki beberapa keterbatasan yang menyebabkan penggunanya sering mengeluh kesakitan di bagian punggung, pinggang, tangan dan telapak tangan karena beban yang diangkut pada gerobak sampah mencapai berat lebih dari sebesar $250 \mathrm{Kg}$. Oleh sebab itu perlu dilakukan perbaikan desain gerobak sampah yang aman, dan nyaman bagi penggunanya.

Gerobak pemulung yang ada dikembangkan melalui reverse engineering, yaitu suatu cara meneliti atau menganalisis suatu system melalui identifikasi komponen-komponen dan keterkaitan antar komponen serta mengekstraksi dan membuat abstraksi dan informasi perancangan dari system yang dianalisis tersebut (Raja \& Fernandes, 2008). Melalui konsep ini, peneliti meniru gerobak yang sudah ada sebagai dasar untuk merancang produk baru yang sejenis, baik dengan merubah desain, memperkecil kelemahan dan meningkatkan keunggulan produk dari para pendahulunya.

Gerobak pemulung dirancang ulang menggunakan pendekatan ergonomis pada dimensi tubuh pengguna. Gerobak sampah pemulung hasil rancangan tersebut diketahui bahwa keluhan Nordic Body Map pemulung menurun dari rata - rata keluhan sebesar 86,5\% menjadi 40,2 \%. Dimensi gerobak pemulung sampah hasil rancangan terbuat dari besi siku dengan tinggi tanpa roda $70 \mathrm{~cm}$, lebar $52 \mathrm{~cm}$ dan panjang $100 \mathrm{~cm}$. Sedangkan jarak pegangan dorongan maupun tarikan dengan batas tepi gerobak dirancang secara adjustable hal ini untuk dapat digunakan secara bolak balik, baik didorong maupun dapat ditarik sehingga pemulung dapat menggunakannya dengan nyaman dan aman. Sedangkan untuk 
pintu gerobag dirancang dua bagian yaitu satu di depan dan satu lagi dibagian samping, hal ini untuk memudahkan pembongkaran sampah.

Berdasarkan permasalahan yang akan diselesaikan, maka dirancang dan dibuat 2 buah gerobak pemulung yang ergonomis yang nantinya diberikan kepada para pemulung di TPA Kecamatan Bandung Wetan Kota Bandung. Gerobak pemulung yang telah dirancang tersebut memiliki keunggulan antara lain terbuat dari barang bekas, biaya pembuatan yang lebih murah, awet, aman dan nyaman digunakan oleh pemulung dan tidak menyebabkan nyeri pada bagian tubuh tertentu, serta diharapkan dapat meningkatkan kinerja pemulung.

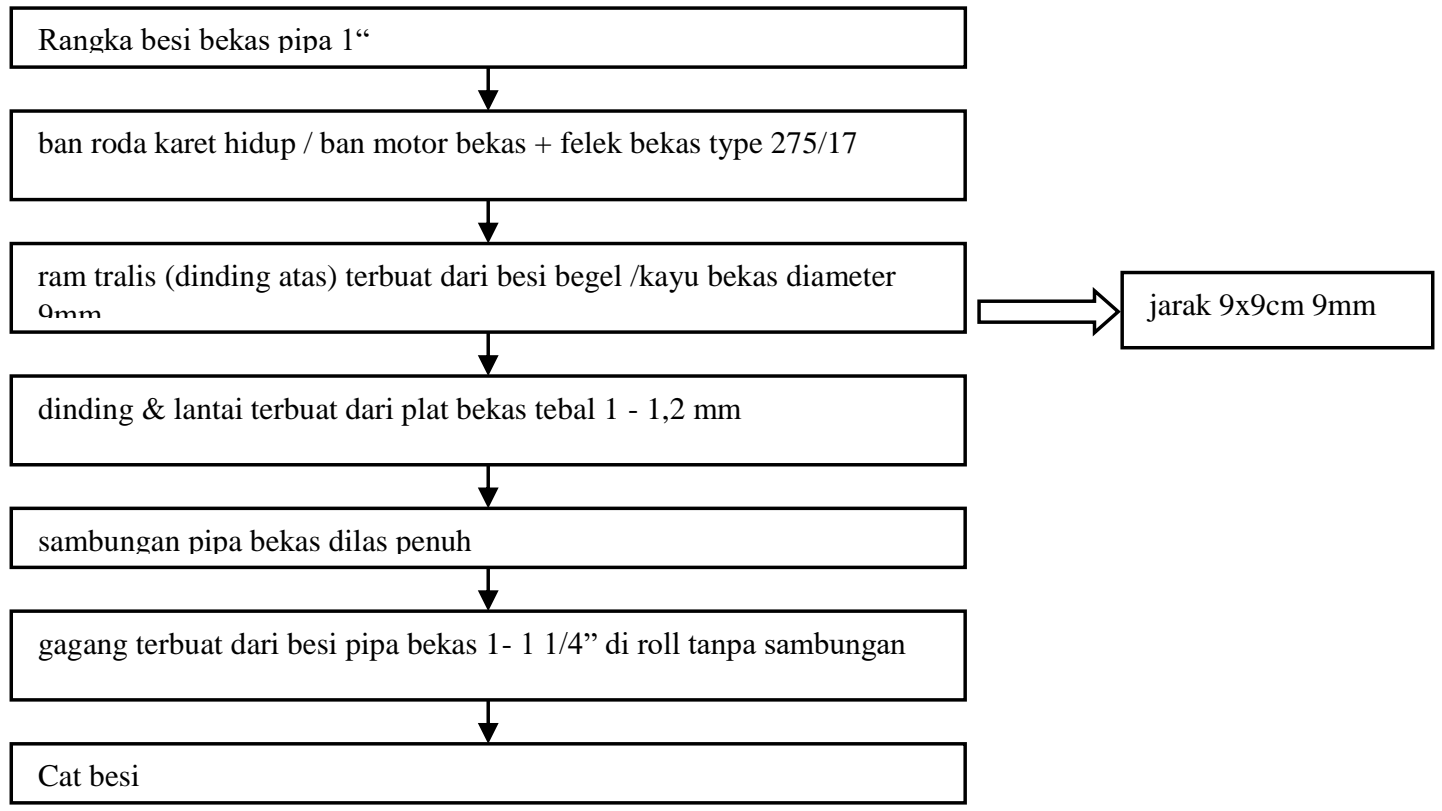

Gambar 2. Flowchart proses pembuatan gerobak

Dalam proses pembuatan gerobak, sebelumnya dilakukan pengukuran sesuai dengan antropometri manusia yang menggunakannya. Peneliti mempelajari dimensi tubuh pemulung guna merumuskan perbedaan-perbedaan ukuran pada tiap individu ataupun kelompok pengguna gerobak nantinya (Panero \& Martin, 1979). Sehingga gerobak yang akan dibuat disesuaikan dengan ukuran tubuh pemulung tersebut. Selain sesuai dengan antropometrinya, desain gerobak ini didesain dengan kemudahan bongkar muat sampah. Selain itu manfaat yang diharapkan perancangan gerobak pemulung yang ergonomis ini adalah memberikan kenyamanan kerja, kesehatan, keselamatan kerja, dan kesesuaian ukuran alat kerja dengan pekerja; menghilangkan pengaruh kurang baik antara pekerja dan peralatan kerja; mencegah dan mengurangi resiko timbulnya penyakit akibat kerja; mengurangi timbulnya kecelakaan kerja; dan meningkatkan produktivitas kerja. 

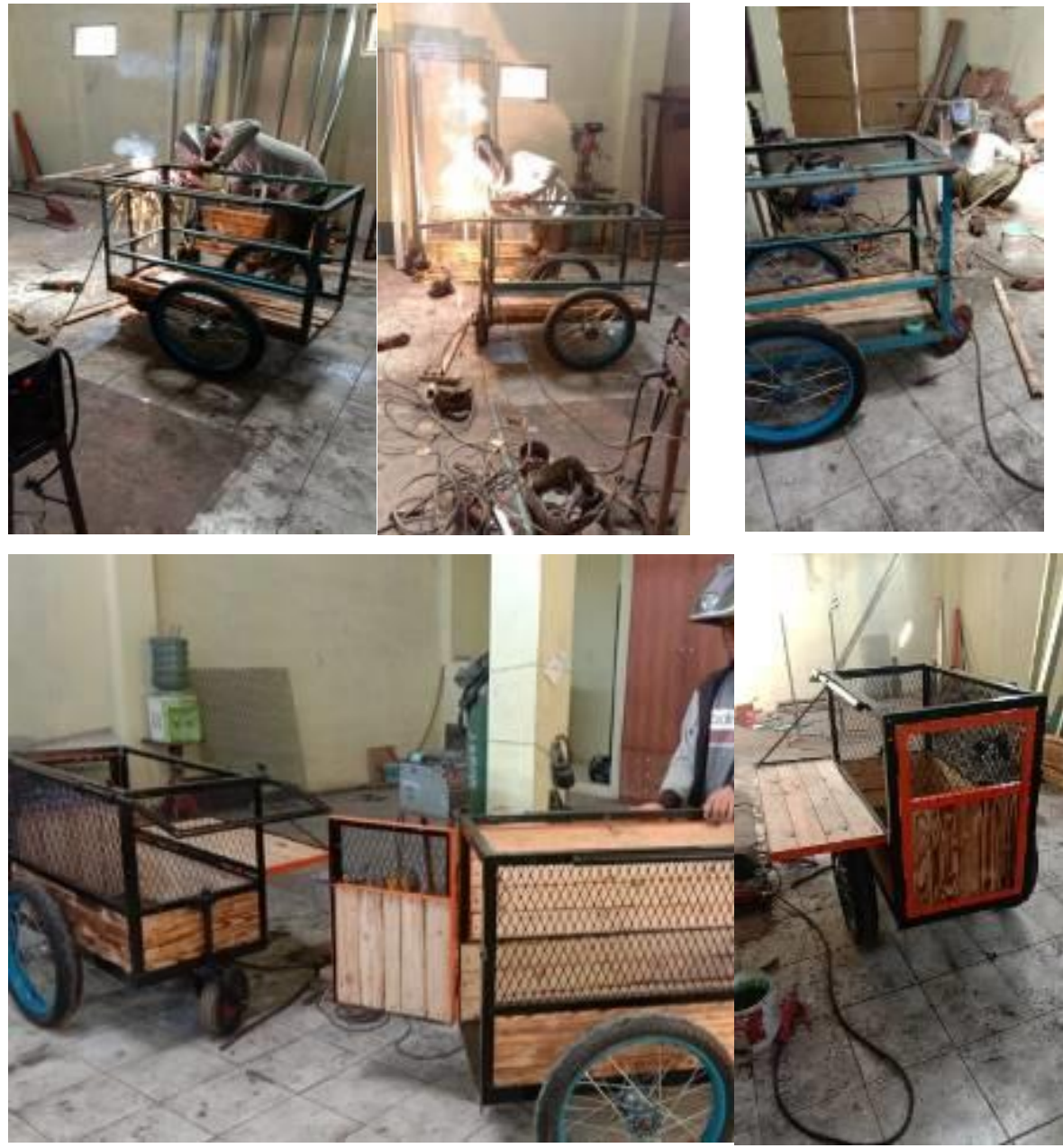

Gambar3. Proses Pengerjaan Gerobak

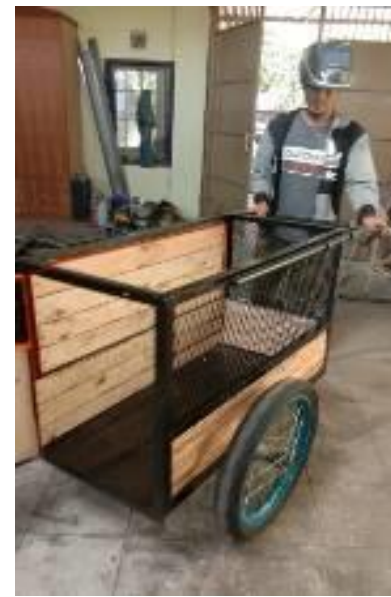

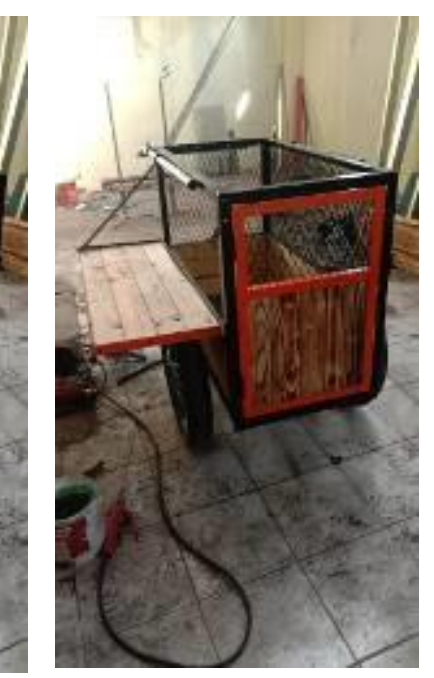

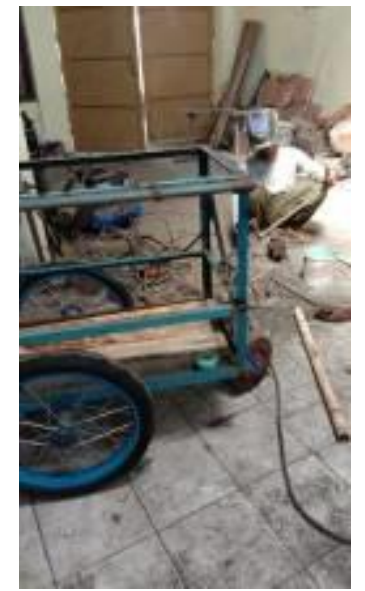

Cambar3. Proses Pengerjaan Gerobak

\section{Pelatihan Kewirausahaan}

Pelatihan ini melibatkan keluarga pemulung yang bertempat tinggal di sekitar TPA Kecamatan Bandung Wetan, Kota Bandung. Berdasarkan permasalahan yang akan diselesaikan, maka diadakan pelatihan pembuatan barang kreativitas dari barang bekas yang berupa limbah botol bekas, limbah kaleng bekas, dan limbah cangkang kopi sachet bekas.

Zimmerer mengemukakan bahwa kewirausahaan sebagai suatu proses penerapan kreativitas dan inovasi dalam memecahkan persoalan dan menemukan peluang untuk memperbaiki kehidupan (usaha) (Anwar, 2014). Peter F. Drucker mengatakan bahwa kewirausahaan adalah praktek kerja yang tertumpu atas konsep dan teori, bukan intuisi, sehingga kewirausahaan dapat dipelajari dan dikuasai secara sistematik dan terencana (Fadiati \& Purwana, 2015).

Tabel 1. Karakteristik responden

\begin{tabular}{cllll}
\hline \multicolumn{1}{c}{ Karakter responden } & & $\mathbf{N}$ & $\mathbf{\%}$ \\
\hline Jenis kelamin & Laki-laki & 5 & $50 \%$ \\
\hline & Perempuan & 5 & $50 \%$ \\
\hline
\end{tabular}




\begin{tabular}{llll}
\hline Usia & $20-30$ tahun & 4 & $40 \%$ \\
\hline & $30-40$ tahun & 5 & $50 \%$ \\
\hline Pendidikan & $>40$ tahun & 1 & $10 \%$ \\
\hline & SD & 3 & $30 \%$ \\
\hline & SMP & 4 & $40 \%$ \\
\hline & SMA & 2 & $20 \%$ \\
\hline $\begin{array}{l}\text { Tidak } \\
\text { bersekolah }\end{array}$ & pernah & 1 & $10 \%$ \\
\hline
\end{tabular}

Sumber : Data Primer (2020)

Pelatihan dilaksanakan dengan mendatangkan instruktur profesional untuk melatih beberapa mahasiswa terpilih dalam membuat kreativitas dari barang bekas. Mahasiswa tersebut kemudian akan melatih para keluarga pemulung tersebut untuk mempraktekkan cara pembuatan barang kreativitas dari barang bekas.

Pelatihan merupakan kegiatan yang dirancang untuk mengembangkan sumber daya manusia melalui rangkaian kegiatan identifikasi, pengkajian serta proses belajar yang terencana. Pelatihan sebagai bagian dari Pendidikan yang mengandung proses belajar untuk memperoleh dan meningkatkan ketrampilan dalam berwirausaha, waktu yang relative singkat dan metode yang lebih mengutamakan praktek dari pada teori. Pelatihan kewirausahaan sebagai program yang cenderung focus dalam membangun pengetahuan dan ketrampilan secara eksplisit dalam persiapan untuk memulai suatu usaha dimana dalam program pelatihan ini, menuntun peserta untuk terlibat ke dalam praktek (Valerio et al., 2014).

Manfaat pelatihan ini antara lain diharapkan agar keluarga pemulung mendapatkan bekal ilmu pengetahuan yang cukup untuk membuat barang kreativitas sederhana berbahan dasar botol plastik bekas, kaleng bekas, cangkang kopi sachet bekas, meningkatkan minat keluarga pemulung pada pembuatan barang kreasi dari bahan bekas yang dapat dijadikan modal dalam berwirausaha, meningkatkan bekal keterampilan yang cukup untuk membuat barang kreasi dari bahan bekas, serta meningkatkan jiwa kewirausahaan dan bekal kompetensi kewirausahaan pada keluarga pemulung.

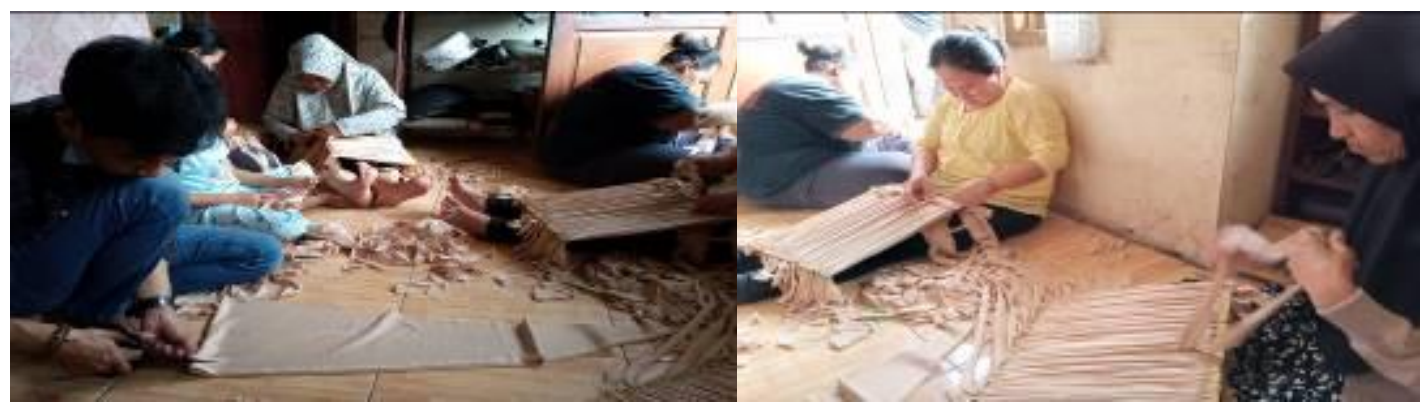

Gambar 4. Pelatihan pembuatan krativitas dari bahan bekas 
Tabel 2 menyajikan hasil produk kerajinan dari barang bekas yang dibuat oleh para pemulung dan capaian penguasaan pemulung terhadap pelatihan yang diberikan. Dari hasil observasi didapatkan bahwa untuk pembuatan keranjang dari botol bekas, dari sepuluh pemulung yang dilatih, sebanyak delapan responden (80\%) telah menguasai teknik pembuatannya, sedangkan sisanya tidak menguasai. Hal tersebut berarti bahwa sebagian besar pemulung telah memahami cara pembuatan keranjang dari barang bekas. Keterampilan ini perlu diberikan kepada para pemulung, karena selain akan meningkatkan kreativitas mereka, juga bertujuan untuk mengurangi penumpukan sampah plastik yang berpotensi menjadi limbah lingkungan.

Tabel 2. Capaian Pelatihan Pembuatan Barang Kreativitas

\begin{tabular}{lllc}
\hline \multirow{2}{*}{ Nama Produk } & Bahan & Capaian & \\
\cline { 3 - 4 } & & Menguasai & $\begin{array}{c}\text { Tidak } \\
\text { Menguasai }\end{array}$ \\
\hline Keranjang pakaian & Botol plastik bekas & $80 \%$ & $20 \%$ \\
\hline Tempat Pensil & Gelas Bekas & $70 \%$ & $30 \%$ \\
\hline Tempat Sikat gigi & Botol plastik bekas & $80 \%$ & $20 \%$ \\
\hline Tempat Pensil & Kaleng bekas & $85 \%$ & $15 \%$ \\
\hline Tas & $\begin{array}{c}\text { Cangkang } \\
\text { bekas }\end{array}$ & $70 \%$ & $30 \%$ \\
\hline
\end{tabular}

Sumber : Data Primer (2020)

Untuk pembuatan tempat pensil, sebanyak tujuh responden (70\%) telah menguasai cara pembuatan barang kreasi tersebut, sedangkan sisanya belum menguasai, karena kekurangan alat bantu dalam proses pengerjaannya. Untuk pembuatan tempat sikat gigi, sebanyak delapan responden $(80 \%)$ telah menguasai dan untuk pembuatan tempat pensil dari kaleng bekas, sebanyak $85 \%$ telah menguasai. Sedangkan untuk pembuatan tas dari cangkang kopi bekas, sebanyak $70 \%$ telah menguasai.

Program ini juga memberikan pelatihan dasar kewirausahaan kepada para pemulung. Dengan melakukan pelatihan UMKM secara singkat dan sederhana kepada para pemulung meliputi 1) pemasaran; dengan memberikan materi basic concept of marketing, target pasar, maupun segmentasi pasar melalui presentasi dan diskusi; 2) keuangan; dengan memberikan materi pencatatan aktivitas keuangan, pengelolaan keuangan sederhana, evaluasi kondisi usaha; serta 3) pelatihan produksi; dengan memberikan materi pembuatan barang yang inovatif dan kreatif, menetapkan harga jual, menetapkan keuntungan atau laba (Anto, 2003).

Pelatihan tersebut diharapkan dapat pendapatan pemulung, terutama dari penjualan barang kreasi yang telah diajarkan. Pendapatan merupakan unsur yang penting dalam usaha perdagangan, karena dalam menjalankan suatu usaha, maka tentu perlu untuk mengetahui jumlah pendapatan yang dihasilkan dari usaha tersebut. Pelatihan ini juga diharapkan dapat meningkatkan motivasi untuk mempelajari keterampilan tertentu yang dapat dijadikan modal berwirausaha. Motivasi diartikan 
sebagai sumber penggerak bagi wirausaha untuk melakukan tindakan agar tujuan dan harapan tercapai. Herzberg menyatakan bahwa motivasi merupakan salah satu faktor keberhasilan wirausaha dalam menyelesaikan tugasnya (Rusdiana, 2018). Semakin tinggi motivasi, maka semakin besar kesuksesan yang dicapai.

Dalam program ini, tim peneliti menemukan beberapa faktor kendala maupun pendukung keberhasilan pelatihan yang diberikan. Faktor penghambat pelaksanaan kegiatan antara lain pemulung kurang memiliki kemauan tekad yang kuat, kurang dalam hal permodalan, kurang memiliki pengetahuan kompetensi kewirausahaan, kurang memiliki keterampilan, kurangnya kemampuan komunikasi yang baik, serta rendahnya inovasi dan kreativitas. Sementara faktor pendukung pelaksanaan kegiatan antara lain adalah adanya kemauan untuk dilatih dan bekerja sama dari pemulung. Selain itu, lokasi tempat pemulung bekerja berada di kota besar dan di poros jalan utama serta barang bekas yang mudah didapatkan juga menjadi faktor penunjang kegiatan ini.

Sebelum dilakukan monitoring eksternal, program ini telah dilakukan monitoring dan evaluasi internal. Tim Peneliti telah mempresentasikan alur dan proses pelaksanaan program di depan LPPM Universitas dan reviewer. Tim peneliti menyampaikan berbagai kendala maupun temuan selama program dilaksanakan.

\section{KESIMPULAN}

Gerobak yang dipergunakan pemulung untuk mengangkut sampah rata rata tidak memiliki ukuran yang standar, hal ini terbukti dari hasil pengamatan pendahuluan dengan menggunakan Nordic Body Map bahwa pemulung sering mengeluh kesakitan di bagian punggung, pinggang, tangan dan telapak tangan, karena beban yang diangkut pada gerobak sampah mencapai berat lebih dari sebesar $250 \mathrm{Kg}$. Oleh sebab perlu dilakukan perbaikan gerobak sampah yang ergonomis bagi penggunanya, dan setelah ada perbaikan gerobag sampah untuk pemulung maka keluhan kesakitan di bagian punggung, pinggang, tangan dan telapak tangan menurun dari rata - rata $86,5 \%$ menjadi $40,2 \%$. Dimensi gerobak pemulung sampah hasil rancangan terbuat dari besi siku dengan tinggi tanpa roda 70 $\mathrm{cm}$, lebar $52 \mathrm{~cm}$ dan panjang $100 \mathrm{~cm}$. Sedangkan jarak pegangan dorongan maupun tarikan dengan batas tepi gerobak dirancang secara adjustable hal ini untuk dapat digunakan secara bolak balik, baik didorong maupun dapat ditarik sehingga pemulung dapat menggunakannya secara ergonomis. Sedangkan untuk pintu gerobak dirancang dua bagian yaitu satu di depan dan satu lagi di bagian samping, hal ini untuk memudahkan pembongkaran sampah.

Walaupun pada dasarnya kreativitas merupakan sifat bawaan, namun banyak pakar yang meyakini bahwa kreativitas dapat diajarkan. Pelatihan kewirausahaan dirancang untuk mengembangkan sumber daya manusia dimana di dalamnya mengandung proses belajar untuk memperoleh dan meningkatkan ketrampilan dalam berwirausaha, waktu yang relative singkat dan metode yang lebih mengutamakan praktek daripada teori. Pelatihan kewirausahaan diharapkan 
membangun pengetahuan dan ketrampilan secara eksplisit dalam persiapan untuk memulai suatu usaha. Pelatihan ini juga diharapkan dapat meningkatkan motivasi untuk mempelajari keterampilan tertentu yang dapat dijadikan modal berwirausaha.

Pelaksanaan program ini tentunya tidak berjalan tanpa kendala. Faktor-faktor tersebut antara lain kurangnya kemauan, permodalan, pengetahuan kompetensi kewirausahaan, keterampilan, kemampuan komunikasi yang baik, serta rendahnya inovasi dan kreativitas. Namun, di balik hal tersebut, mitra program memiliki kemauan untuk dilatih dan bekerja sama. Lokasi program yang berada di kota besar juga menjadi faktor penunjang kegiatan ini.

\section{UCAPAN TERIMAKASIH}

Puji syukur senantiasa tim pengabdi panjatkan ke hadirat Allah SWT yang telah melimpahkan Rahmat serta Petunjuk-Nya, sehingga Pengabdian Kepada Masyarakat ini dapat diselesaikan. Pengabdian pada Masyarakat mengambil judul: Perancangan Gerobak Pemulung Sampah Yang Ergonomis. Oleh karena itu dalam kesempatan ini tim pengabdi ingin menyampaikan penghargaan dan ucapan terimakasih yang sebesar-besarnya kepada pihak-pihak telah memberikan bantuan dalam rangka penyelesaian laporan ini yaitu:

1. Rektor UNLA yang telah memberi kesempatan dan bantuan untuk pelaksanaan Pengabdian Kepada Masyarakat ini.

2. Dekan FT-UNLA yang telah memberi kesempatan dan bantuan untuk pelaksanaan Pengabdian Kepada Masyarakat.

3. LPPM UNLA yang telah memberi kesempatan dan bantuan sejak pengajuan proposal sampai penyusunan laporan akhir.

4. Tidak lupa juga kepada mitra masyarakat khususnya Kecamatan Bandung Wetan dalam pelaksanaan kegiatan pengabdian masyarakat atas kerjasamanya.

5. Terimaksih pula kami ucapan kepada pihak yang telah memberikan pendanaan baik dari UNLA maupun pendanaan dari Hibah Ristekdikti.

6. Semua pihak yang tidak dapat tim pengabdi sebutkan satu per satu yang telah banyak membantu terselenggaranya pengabdian kepada masyarakat ini. Semoga Allah SwT berkenan melimpahkan pahala sesuai jasa-jasa beliau.

Tim pengabdi menyadari bahwa hal yang disajikan dalam artikel ini masih banyak kekurangan. Oleh karena itu saran dan kritik yang bersifat membangun sangat diharapkan.

\section{DAFTAR PUSTAKA}

Anwar, Muhammad. 2014. Pengantar Kewirausahaan Teori dan Aplikasi. Kencana

Fadiati, Ari. 2011. Menjadi Wirausaha Sukses: Rosda

Jatmiko, Bambang. 2014. Metode Penelitian: Bandung

Mulyadi, 2010. Kewirausahaan dan Manajemen Usaha Kecil: Alfabeta 
Sarwono, Jonathan. 2013. Metode Penelitian Kuantitatif dan Kualitatif. Yogyakarta: Graha Ilmu

Sekaran, Uma. 2013. Metodologi Penelitian Untuk Bisnis. Jakarta: Salemba Empat

Sudrajat, 2011. Kiat Mengentaskan Pengangguran dan Kemiskinan Melalui Wirausaha: Bumi Aksara

Sudrajat. 2011. Kiat Mengentaskan Pengangguran Melalui Wirausaha: Bumi Aksara

Sugiyono. 2009. Metode Penelitian Kuantitatif Kualitatif Dan R\&D. Bandung: Alfabeta

Sugiyono. 2013. Metode Penelitian Bisnis. Bandung: Alfabeta

Supangat, Andy. 2013. Statistika. Bandung: Pustaka

Suryana. 2003. Kewirausahaan: Pedoman Praktis, Kilat dan Proses Menuju Sukses. Jakarta: PT Salemba Empat

Suryana. 2013. Kewirausahaan Kiat dan Proses Menuju Sukses: Salemba Empat

Suryana. 2013. Kewirausahaan (Kiat dan Proses Menuju Sukses): Gudang Penerbit

Umar, Husein. 2012. Metode Penelitian Untuk Skripsi dan Tesis Bisnis. Jakarta: PT. Raja Grafindo Persada 